\title{
Foreword by Yi, Ji-Ming
}

I am happy to write this foreword for James in order to introduce the latest development in the Chinese pharmaceutical patent system to the western world.

James Hou was my PhD student at Peking University ('PKU') Law School from 2012 to 2017. He had an abundant life at PKU. When he entered into PKU, he just founded his law firm in Taipei. He decided to move to Mainland China with his wife. During the five years at PKU, a beautiful daughter was born to him, and he also founded an intellectual property consulting company in Nanjing. Both his career and family are successful in China.

After James passed his PhD examination, I immediately suggested that he should try to publish his dissertation, which forms the main body of this book.

China's intellectual property environment was under huge changes during the years when James was at PKU. China has been in a transformative process from a piracy country to a country with strong intellectual property protection since the National Intellectual Property Strategy Guidelines were issued in 2015. In terms of the numbers of patent applications, China has consistently ranked number one for the past several years. China also established three Intellectual Property Courts based on the American model of Court of Appeals for the Federal Circuit. Meanwhile, the Chinese government initiated a Mass Entrepreneurship and Innovation Program in order to encourage people to innovate. Furthermore, after the painful economic transition in the early twentieth century, the Chinese government has decided to enforce the strictest intellectual property protection system. Its goal is to establish an innovation-driven economic mechanism and an innovative country. The slogan is 'An IP Big Country Now, An IP Strong Country in the Future'. James' research work and business perfectly match China's development. First, he used the academic tools that he learned at PKU to research the pharmaceutical patent issues. Second, he used the intellectual property knowledge to establish his consulting company and even host several influential intellectual property forums, such as the Cross-Strait Intellectual Property Management Forum. His research is the cornerstone of his business and his business makes his academic concept become real.

James' book talks about the issues surrounding the commercialization of Chinese pharmaceutical patents. Pharmaceutical patent is not only an intellectual property research topic but also related to economy and politics. 
Therefore, it is very important, complicated and sensitive. From the standpoint of the Chinese government, it has to foster local pharmaceutical industry, and in order to accomplish it, a good intellectual property protection environment and a fair competition market are crucial according to the American experience. Consequently, the commercialization of pharmaceutical patents is multifarious, relating to legal, economic, public policy, etc. James is bold to challenge this topic, and he acquires fruitful results.

As James' $\mathrm{PhD}$ supervisor, I am glad to see his success in both research and business. There is no end for the pursuit of knowledge. I expect to see his further growth. 